\title{
PENYULUHAN KESEHATAN DIABETES MELITUS PENATALAKSNAAN DAN APLIKASI SENAM KAKI PADA LANSIA DI WILAYAH PESISIR SURABAYA
}

\author{
Hidayatus Sya'diyah, Dini Mei Widayanti, Yoga Kertapati, Sapto Dwi Anggoro, \\ Akif Ismail, Theresia Atik, Dimas Gustayansyah \\ STIKes Hang Tuah Surabaya \\ mahisyah sht@yahoo.com
}

\begin{abstract}
ABSTRAK
Diabetes Melitus adalah gangguan metabolisme yang secara genetis dan klinis termasuk heterogen dengan manifestasi berupa hilangnya toleransi karbohidrat (Price, 2006). Komplikasi yang dapat terjadi antara lain komplikasi akut dan komplikasi kronis. Apabila hal ini terjadi pada lansia dimana mengalami berbagai penurunan fisik, psikologis, sosial, spiritual dan kultural sehingga dapat menimbulkan resiko komplikasi yang lebih memerlukan perhatian.Tujuan pengabdian masyarakat ini adalah memberikan penyuluhan tentang Diabetes Melitus tentang penataksanaaanya dan aplikasi senam kaki. Metode penyuluhan yang dilakukandenganbeberapa tahapan, yaitu : 1) Sosialisasi dan perijinan, 2) Persiapan alat dan sarana serta media penyuluha, 3) Melakukan penyuluhan dan aplikasi 4) Evalausi hasil kegiatan penyuluhan. Hasil penyuluhan Diabetes Melitus dan aplikasi senam kaki pada lansia, di akhir sesi yaitu beberapa lansia diberikan pertanyaan mengenai apa yang telah disuluhkan antara lain pengertian Diabetes Melitus, bagaimana tanda dan gejalanya, etiologi atau faktor-faktor yang menyebabkan Diabetes Melitus, upaya dan pencegahannya, komplikasi yang dapat muncul serta mendemonstrasikan kembali senam kaki yang telah dilaksanakan. Pengembangan program pengabdian masyarakat bidang peningkatan kualitas kesehatan lansia yang terintegrasi dengan program akademik, pemerintah dan stakeholder (mitra) perlu terus ditingkatkan. Serta perlunya kegiatan pengabdian masyarakat secara berkala dan berkelanjutan untuk lebih menggali lagi lebih dalam dalam masalah-masalah kesehatan yang dihadapi oleh para lansia
\end{abstract}

\section{ABSTRACT}

Diabetes mellitus is a metabolic disorder that genetically and clinically including heterogeneous with manifestations in the form of loss of carbohydrate tolerance (Price, 2006). Complications that can occur include acute complications and chronic complications. If this happens to the elderly, who experience a variety of physical, psychological, social, spiritual and cultural decline that can lead to risks of complications that require more attention. The aim of community service is to provide counseling about Diabetes Mellitus about its management and application of foot exercises. Counseling methods carried out with several stages, namely: 1) Socialization and licensing, 2) Preparation of tools and facilities and extension media, 3) Conducting counseling and application 4) Evalausiing the results of extension activities. The results of Diabetes Mellitus counseling and application of foot gymnastics in the elderly, at the end of the session, some 
elderly people were asked questions about what had been healed including understanding Diabetes Mellitus, how the signs and symptoms, etiology or factors that cause Diabetes Mellitus, efforts and prevention, complications which can appear and demonstrate again the leg exercises that have been implemented. The development of community service programs in the field of improving the quality of elderly health that is integrated with academic programs, government and stakeholders (partners) needs to be continuously improved. And the need for community service activities on a regular and ongoing basis to dig deeper into deeper health problems faced by the elderly. 


\section{PENDAHULUAN}

Diabetes Melitus adalah gangguan metabolisme yang secara genetis dan klinis termasuk heterogen dengan manifestasi berupa hilangnya toleransi karbohidrat [1]. Diabetes Melitus (DM) merupakan kelainan metabolik dimana ditemukan ketidakmampuan untuk mengoksidasi karbohidrat, akibat gangguan pada mekanisme insulin yang normal, menimbulkan hiperglikemia, glikosuria, poliuria, rasa haus, rasa lapar, badan kurus, kelemahan, asidosis, sering menyebabkan dispnea, lipemia, ketonuria dan akhirnya koma [2]. Hiperglikemia merupakan keadaan peningkatan glukosa darah dari rentang kadar puasa normal $80-90$ $\mathrm{mg} / \mathrm{dl}$ darah, atau rentang non puasa sekitar 140-160 mg/100 ml darah [3]. Apalagi hal ini terjadi pada lansia dimana mengalami berbagai penurunan fisik, psikologis, sosial, spiritual dan kultural sehingga dapat menimbulkan resiko komplikasi yang lebih memerlukan perhatian.

Pada tahun 2000, berdasar laporan WHO dalam jurnal "Global Prevalence of Diabetes Estimates for the year 2000 and Projections for 2030", sekitar 171 juta penduduk diseluruh dunia telah menderita diabetes. Angka tersebut setara dengan 2,8\% dari total penduduk di seluruh dunia. Insidensi kejadian diabetes memang mengalami peningkatan dengan cepat, dan diperkirakan pada tahun 2030, jumlah penderita diabetes akan menigkat tajam menjadi 2 kali lipat. Diabetes mellitus terjadi di seluruh dunia, akan tetapi umumnya ditemukan di negara-negara berkembang, khususnya untuk kasus diabetes tipe 2 . Peningkatan prevalensi kesakitan terbesar diperkirakan akan terjadi di kawasan Asia dan Afrika. Peningkatan kasus diabetes di negara-negara berkembang sebagian besar merupakan dampak dari adanya urbanisasi dan perubahan gaya hidup.

Berdasarkan studi yang telah dilakukan oleh WHO menggunakan desain studi kohort di seluruh dunia selama kurang lebih 11 tahun diperoleh data bahwa angka kematian akibat diabetes pada tahun 2000 diperkirakan sekitar 2,9 juta kematian dimana 1,4 juta adalah laki-laki dan 
1,5 juta perempuan. Angka ini setara dengan $5,2 \%$ dari seluruh kematian dengan berbagai sebab di seluruh dunia pada tahun 2000. Jika dipisahkan berdasarkan tingkat kemajuan sebuah negara, maka didapatkan angka bahwa angka kematian akibat diabetes pada tahun 2000 di negara maju sebesar 1 juta orang dan di negara berkembang sebesar 1,9 juta orang. Angka kematian akibat diabetes terandah $(2,4 \%)$ terdapat pada negaranegara miskin di afrika, kamboja, laos, myanmar dan vietnam. Sementara itu angka kematian akibat diabetes tertinggi adalah 9\% di negara-negara timur tengah semenanjung arab dan $8,5 \%$ di negara-negara kawasan amerika. Negara-negara dengan angka prevalensi kematian tinggi akibat diabetes pada kelompok dengan usia muda seperti di kawasan Asia Tenggara, semenanjung arab, kawasan timur tengah, dan kawasan timur pasifik memiliki kecanderungan umur tertinggi untuk kematian akibat diabetes adalah berkisar antara 50-54 tahun. Akan tetapi secara umum di seluruh dunia, angka kematian akibat diabetes tertinggi terjadi pada usia sekitar 55-59 tahun. Sementara itu untuk angka kesakitan diabetes, diperoleh data bahwa pada negara berkembang, kebanyakan orang yang menderita diabetes adalah usia 45 sampai 64 tahun. Keadaan yang sangat berkebalikan terlihat di negera-negara maju dimana umumnya orang yang menderita diabetes di negar maju adalah orang yang berumur 64 tahun keatas.

Secara keseluruhan, 7,5 juta penduduk yang menderita diabetes diperkirakan telah meninggal pada tahun 2000. Angka tersebut terdiri dari 4,6 juta penduduk yang menderita diabetes namun diasumsikan meninggal karena penyebab lain (non-diabetes), ditambah dengan 2,9 juta penduduk yang menderita diabetes dan meninggal akibat diabetes yang dideritanya. Pada seseorang dengan umur kurang dari 35 tahun yang menderita diabetes, $75 \%$ diantaranya meninggal akibat diabetes yang dideritanya; pada penduduk dengan usia 35-64 tahun yang menderita diabetes, 59\% diantaranya meninggal akibat diabetes yang dideritanya; dan pada seseorang dengan usia lebih dari 64 tahun yang menderita 
diabetes, 29\% diantaranya meninggal akibat diabetes yang dideritanya. Berikut data presentase kematian akibat diabetes dan presentase total kematian akibat sebab umum yang dikelompokkan menurut umur:

Etologi dari Hiperglimia pada Diabetes Melitus antara lain terjadi karena tidak adekuat produksi insulin oleh pankreas, terjadi peningkatan kebutuhan insulin, kelainan sel beta pankreas, berkisar dari hilangnya sel beta sampai kegagalan sel beta melepas insulin, faktor - faktor lingkungan yang mengubah fungsi sel beta, antara lain agen yang dapat menimbulkan infeksi, diet dimana pemasukan karbohidrat dan gula yang diproses secara berlebihan, obesitas dan kehamilan, gangguan sistem imunitas. Sistem ini dapat dilakukan oleh autoimunitas yang disertai pembentukan sel - sel antibodi antipankreatik dan mengakibatkan kerusakan sel - sel penyekresi insulin, kemudian peningkatan kepekaan sel beta oleh virus.Kelainan insulin. Pada pasien obesitas, terjadi gangguan kepekaan jaringan terhadap insulin akibat kurangnya reseptor insulin yang terdapat pada membran sel yang responsir terhadap insulin.Etiologi lain : pankreatitis, tumor pankreas, obesitas, hipertiroid, akromegali, kehamilan, infeksi.

Sebagian besar gambaran patologik dari DM dapat dihubungkan dengan salah satu efek utama akibat kurangnya insulin berikut: berkurangnya pemakaian glukosa oleh sel-sel tubuh yang mengakibatkan naiknya konsentrasi glukosa darah setinggi 300-1200 mg/dl, peningkatan mobilisasi lemak dari daerah penyimpanan lemak yang menyebabkan terjadinya metabolism lemak yang abnormal disertai dengan endapan kolestrol pada dinding pembuluh darah, berkurangnya protein dalam jaringan tubuh dimana pasien-pasien yang mengalami defisiensi insulin tidak dapat mempertahankan kadar glukosa plasma puasa yang normal atau toleransi sesudah makan. Pada hiperglikemia yng parah yang melebihi ambang ginjal normal (konsentrasi glukosa darah sebesar 160$180 \mathrm{mg} / 100 \mathrm{ml}$ ), akan timbul glikosuria karena tubulus-tubulus renalis tidak dapat menyerap kembali semua glukosa. Glukosuria ini akan 
mengakibatkan diuresis osmotik yang menyebabkan poliuri disertai kehilangan sodium, klorida, potasium, dan pospat. Adanya poliuri menyebabkan dehidrasi dan timbul polidipsi. Akibat glukosa yang keluar bersama urine maka pasien akan mengalami keseimbangan protein negatif dan berat badan menurun serta cenderung terjadi polifagi. Akibat yang lain adalah astenia atau kekurangan energi sehingga pasien menjadi cepat telah dan mengantuk yang disebabkan oleh berkurangnya atau hilangnya protein tubuh dan juga berkurangnya penggunaan karbohidrat untuk energi.

Hiperglikemia yang lama akan menyebabkan arterosklerosis, penebalan membran basalis dan perubahan pada saraf perifer. Ini akan memudahkan terjadinya gangren. Adapun tanda dan gejala pasien dengan Diabetes Melitus antara lain: poliuria, polidipsia, polifagia, mudah mengantuk/lelah, berat badan yang menurun dengan cepat, luka susah sembuh, gangguan seksual, infeksi vaginal, penglihatan kabur, kesemutan

Peran perawat edukasi Diabetes merupakan suatu proses pendidikan dan pelatihan tentang pengetahuan Diabetes dan ketrampilan yang dapat menunjang perubahan perilaku yang diperlukan untuk mencapai tingkat kesehatan yang optimal, penyesuaian psikologis dan kualitas hidup yang lebih baik secara berkelanjutan. Dalam pelaksanaannya perlu dilakukakan beberapa kali pertemuan untuk menyegarkan, mengingatkan kembali prinsip penatalaksanaaan Diabetes sehingga dapat merawat dirinya secara mandiri. Hidup sehat dengan diabetes memerlukan adaptasi Psikososial yang positif, dan penatalaksanaan mandiri yang afektif terhadap penyakit ini. Untuk mencapai penatalaksanaan mandiri yang efektif penderita dengan diabetes harus mengetahui, memepunyai sikap, dan terampil melakukan perawatan mandiri yang berhubungan dengan pengendalian penyakit kronis ini. Pengalamam mengatakan bahawa edukasi terncana seperti akan lebih efektif bila diberikan oleh edukator diabetes yang berkualitas. Edukasi diabetes dianggap sebagai salah satu cara terapi dan merupakan 
bagian integral keperawatan orang dengan diabetes. Beberapa prinsip yang perlu diperhatikan pada proses edukasi diabetes antara lain memberikan dukungan dan nasehat yang positif dan hindari terjadinya kecemasan, menyampaikan informasi secara bertahap jangan berikan beberapa hal sekaligus, mulailah dengan hal yang sederhan baru kemudian dengan hal yang lebih komplek, gunakan alat bantu dengan dengar-pandang (Audio-visual AID), utamakanlah pendekatan dengan mengatasi masalah dan lakukan simulasi, memberikan pengobatan yang sederhana agar kepatuhan mudah dicapai, usahakanlah kompromi dan negosiasi, jangan paksakan tujuan, berikanlah motivasi dan penghargaan dan diskusikanlah hasil laboratorium.

Edukator diabetes didefinisikan sebagai tenaga kesehatan profesional yang menguasai inti pengetahuan dan mempunyai pengetahuan dalam ilmu biologi, sosial, komunikasi, konseling, dan telah berpengalaman dalam merawat orang dengan diabetes. Tanggung jawab utama edukator diabetes adalah pendidkan orang dengan DM, keluarganya dan sistem pendukungnya yang menyangkut penatalaksanaan mandirri dan masalah-masalah yang berhubungan dengan DM. Proses edukasi ini sebaiknya terdiri dari topik-topik antara lain patofisiologi DM, pengelolaan nutrisi dan diet, intervensi farmakologik, aktifitas dan olah raga, pemantauan mandiri kadar glukosa darah, pencegahan dan pengelolaan komplikasi akut dan kronik, penyesuaian psikososial, ketrampilan mengatasi masalah, pengelolaan stress, penggunaan sistem pelayanan kesehatan.

\section{METODE PELAKSANAAN}

Tempat dan Waktu :

Penyuluhan kesehatan tentang Diabetes Melitus, penatalaksanaan dan aplikasi senam kaki dilakukan pada hari Selasa, 12 Nopember 2019 di RT.01 RW.03 kelurahan Sukolilo Baru kecamatyan Bulak 
Tahapan dan Metode Pelaksanaan Kegiatan :

Kegiatan pelaksanaan penyuluhan Diabetes Melitus, penatalaksanaan dan aplikasi senam kaki terdiri atas beberapa tahapan, yaitu : 1) Sosialisasi dan perijinan, 2) Persiapan alat dan sarana serta media penyuluhan, 3) Melakukan penyuluhan dan aplikasi 4) Evaluasi hasil kegiatan penyuluhan

1) Sosialisasi dan Perijinan

Tahap awal yang hars dilakukan adalah sosialisasi damn perijinan kepada pihak lahan untuk mendapatkan persetujuan waktu dan tempat, selanjutnya melakukan sosialisasi kepada para kader lansia untuk mengerakkan para lansia hadir dalam kegiatan pengabdian masyarakat yang akan dilakukan

2) Persiapan alat dan sarana serta media

Aalat dan sarana yang dipersiapkan pada kegiatan ini adalah media penyuluhan antara lain lembar balik, leaflet, power point dan media koran untuk senam kaki diabetik. Selain itu laptop dan LCD, sound musik melengkapi sarana untuk penyuluhan dan aplikasi senam kaki yang dilakukan

3) Penyuluhan Diabetes Melitus dan Aplikasi Senam Kaki

Proses kerja penyuluhan kesehatan yang pertama adalah menyeleksi para lansia yang memenuhi kriteria inklusi yaitu lansia baik yang sudah dan belum terdiagnosa Diabetes Melitus. Kemudian lansia dikumpulkan di Ruang PAUD Kenanga di RT.01 RW.03 kelurahan Sukolilo Baru kecamatyan Bulak, dilakukan kegiatan pre penyuluhan tentang pengetahuan lansia tentang Diabetes Melitus, membagikan leaflet, pemaparan penyuluhan, aplikasi senam kaki dengan melaksanakan role play langsung oleh fasilitator dan diikuti oleh lansia serta evaluasi tingkat penyuluhan lansia dan para kader lansia.

4) Evaluasi hasil kegiatan penyuluhan pre dan post penyuluhan

Tahap evaluasi dilakukan di akhir sesi yaitu beberapa lansia diberikan pertanyaan mengenai apa yang telah disuluhkan antara 
lain pengertian Diabetes Melitus, bagaimana tanda dan gejalanya, etiologi atau faktor-faktor yang menyebabkan Diabetes Melitus, upaya dan pencegahannya, komplikasi yang dapat muncul serta mendemonstrasikan kembali senam kaki yang telah dilaksanakan

\section{HASIL DAN PEMBAHASAN}

Tabel 1 Distribusi Lansia Berdasarkan Usia, JenisKelamin, Riwayat Keluarga Mendetita DM, Lama Menderita DM, Aktifitas Fisik, Lingkar Perut, Riwayat Hipertensi, IMT, Hasil GDA, Hasil Asam Urat

\begin{tabular}{|c|c|c|c|c|}
\hline Kategori & Klasifikasi & Frekuensi & Persentase & Jumkah \\
\hline \multirow[t]{4}{*}{ Usia } & PraLansia $<60$ & 20 & 36 & 56 \\
\hline & Lansia $60-74$ & 32 & 57 & $(100 \%)$ \\
\hline & LansiaTua 75 - 90 & 4 & 7 & \\
\hline & LansiaSangatTua>90 & 0 & 0 & \\
\hline \multirow[t]{2}{*}{ Jenis Kelamin } & Laki - laki & 3 & 5 & 56 \\
\hline & Perempuan & 53 & 95 & $(100 \%)$ \\
\hline \multirow{2}{*}{$\begin{array}{c}\text { Riwayat } \\
\text { keluarga DM }\end{array}$} & Memiliki & 6 & 10 & 56 \\
\hline & Tidakada & 50 & 90 & \\
\hline \multirow[t]{4}{*}{ Lama DM } & Tidaktahu & 47 & 84 & 56 \\
\hline & $<1$ tahun & 0 & 0 & $(100 \%)$ \\
\hline & $1-5$ tahun & 7 & 13 & \\
\hline & $>5$ tahun & 2 & 3 & \\
\hline \multirow[t]{4}{*}{ Aktifitas Fisik } & Tidak tahu & 1 & 2 & 56 \\
\hline & $<1$ jam & 11 & 20 & $(100 \%)$ \\
\hline & $1-2$ jam & 39 & 70 & \\
\hline & $>3$ jam & 5 & 8 & \\
\hline \multirow[t]{2}{*}{ Lingkar perut } & Perempuan $<80 \mathrm{~cm}$ & 53 & 95 & 56 \\
\hline & Laki-laki<90 cm & 3 & 5 & $(100 \%)$ \\
\hline \multirow{3}{*}{$\begin{array}{c}\text { Riwayat } \\
\text { Hipertensi }\end{array}$} & Hipertensi & 8 & 15 & \\
\hline & Normal & 35 & 63 & \\
\hline & Hipotensi & 12 & 22 & \\
\hline \multirow[t]{4}{*}{ IMT } & Kurus 17-19,9 & 4 & 7 & 56 \\
\hline & Ideal $20-24,9$ & 9 & 16 & $(100 \%)$ \\
\hline & Over weight $25-29,9$ & 12 & 22 & \\
\hline & Obesitas $>30$ & 31 & 55 & \\
\hline \multirow[t]{3}{*}{ Hasil GDA } & Hipoglikemi<100 & 8 & 14 & 56 \\
\hline & Normal 100-199 & 39 & 70 & $(100 \%)$ \\
\hline & Hiperglikemi & 9 & 16 & \\
\hline \multirow[t]{4}{*}{ Hasil asam urat } & Perempuan 3-5,9 & 20 & 35 & 56 \\
\hline & Perempuan $>6$ & 32 & 58 & $(100 \%)$ \\
\hline & Laki-laki 3-6,9 & 4 & 7 & \\
\hline & Laki-laki>7 & 0 & 0 & \\
\hline
\end{tabular}


Tabel di atas menunjukkan bahwa lansia rata-rata berusia 60-74 tahun, berjenis kelamin perempuan, memiliki riwayat keluarga DM meskipun 6 lansia, lama menderita DM tidak mengetahui, melakukan aktifitas fisik 1-2 jam, memiliki terkanan darah normal, hasil Index Massa Tubuh dalam kategori obesitas $>30$, hasil Gula Darah Acak dalam kategori normal 100-199 mg/dl, hasil pemeriksaan asam urat pada lansia perempuan $>6$ dan laki-laki 3-6,9

Penyuluhan kesehatan yang dilakukan dengan mempertimbangkan hasil pemeriksaan kesehatan di atas. Adapun perubahan fisik lansia antara lain :

a. Sel: jumlahnya lebih sedikit tetapi ukurannya lebih besar, berkurangnya cairan intra dan extra seluler

b. Persarafan: cepatnya menurun hubungan persarapan, lambat dalam respon waktu untuk meraksi, mengecilnya saraf panca indra sistem pendengaran, presbiakusis, atrofi membran timpani, terjadinya pengumpulan serum karena meningkatnya keratin

c. Sistem penglihatan: pupil timbul sklerosis dan hilangnya respon terhadap sinaps, kornea lebih berbentuk speris, lensa keruh, meningkatnya ambang pengamatan sinar, hilangnya daya akomodasi, menurunnya lapang pandang.

d. Sistem Kardiovaskuler: katup jantung menebal dan menjadi kaku, kemampuan jantung memompa darah menurun $1 \%$ setiap tahun setelah berumur 20 tahun sehingga menyebabkan menurunnya kontraksi dan volume, kehilangan elastisitas pembuluh darah, tekanan darah meninggi.

e. Sistem respirasi: otot-otot pernafasan menjadi kaku sehingga menyebabkan menurunnya aktivitas silia. Paru kehilangan elastisitasnya sehingga kapasitas residu meningkat, nafas berat. Kedalaman pernafasan menurun.

f. Sistem gastrointestinal: kehilangan gigi, sehingga menyebkan gizi buruk, indera pengecap menurun karena adanya iritasi selaput lendir 
dan atropi indera pengecap sampai 80\%, kemudian hilangnya sensitifitas saraf pengecap untuk rasa manis dan asin.

g. Sistem genitourinaria: ginjal mengecil dan nefron menjadi atrofi sehingga aliran darah ke ginjal menurun sampai 50\%, GFR menurun sampai 50\%. Nilai ambang ginjal terhadap glukosa menjadi meningkat. Vesika urinaria, otot-ototnya menjadi melemah, kapasitasnya menurun sampai 200 cc sehingga vesika urinaria sulit diturunkan pada pria lansia yang akan berakibat retensia urine. Pembesaran prostat, $75 \%$ dialami oleh pria diatas 55 tahun. Pada vulva terjadi atropi sedang vagina terjadi selaput lendir kering, elastisitas jaringan menurun, sekresi berkurang dan menjadi alkali.

h. Sistem endokrin: pada sistem endokrin hampir semua produksi hormon menurun, sedangkan fungsi paratiroid dan sekresinya tidak berubah, aktivitas tiroid menurun sehingga menurunkan basal metabolisme rate (BMR). Produksi sel kelamin menurun seperti: progesteron, estrogen dan testosteron.

i. Sistem integumen: pada kulit menjadi keriput akibat kehilangan jaringan lemak, kulit kepala dan rambut menipis menjadi kelabu, sedangkan rambut dalam telinga dan hidung menebal. Kuku menjadi keras dan rapuh.

j. Sistem muskuloskeletal: tulang kehilangan densitasnya dan makin rapuh menjadi kiposis, tinggi badan menjadi berkurang yang disebut discusine vertebralis menipis, tendon mengkerut dan atropi serabut erabit otot, sehingga lansia menjadi lamban bergerak, otot kram, dan tremor.

Lansia dengan berbagai keterbatasan dan kemunduran fisik perlu dilakukan pencegahan terhadap penyakit degeneratif termasuk Diabetes Melitus sehingga Stikes Hang Tuah Surabaya berserta tim mengadakan penyuluhan kesehatan Diabetes Melitus mulai dari pengertian, etiologi, pencegahan, komplikasi dan penatalaksanaan baik pengobatan maupun 
perawatan. Edukator diabetes didefinisikan sebagai tenaga kesehatan profesional yang menguasai inti pengetahuan dan mempunyai pengetahuan dalam ilmu biologi, sosial, komunikasi, konseling, dan telah berpengalaman dalam merawat orang dengan diabetes. Tanggung jawab utama edukator diabetes adalah pendidkan orang dengan DM, keluarganya dan sistem pendukungnya yang menyangkut penatalaksanaan mandirri dan masalah-masalah yang berhubungan dengan DM. Proses edukasi ini sebaiknya terdiri dari topik-topik antara lain patofisiologi DM, pengelolaan nutrisi dan diet, intervensi farmakologik, aktifitas dan olah raga, pemantauan mandiri kadar glukosa darah, pencegahan dan pengelolaan komplikasi akut dan kronik, penyesuaian psikososial, ketrampilan mengatasi masalah, pengelolaan stress, penggunaan sistem pelayanan kesehatan.

Etologi dari Hiperglimia pada Diabetes Melitus antara lain terjadi karena tidak adekuat produksi insulin oleh pankreas, terjadi peningkatan kebutuhan insulin, kelainan sel beta pankreas, berkisar dari hilangnya sel beta sampai kegagalan sel beta melepas insulin, faktor - faktor lingkungan yang mengubah fungsi sel beta, antara lain agen yang dapat menimbulkan infeksi, diet dimana pemasukan karbohidrat dan gula yang diproses secara berlebihan, obesitas dan kehamilan, gangguan sistem imunitas. Sistem ini dapat dilakukan oleh autoimunitas yang disertai pembentukan sel - sel antibodi antipankreatik dan mengakibatkan kerusakan sel - sel penyekresi insulin, kemudian peningkatan kepekaan sel beta oleh virus.Kelainan insulin. Pada pasien obesitas, terjadi gangguan kepekaan jaringan terhadap insulin akibat kurangnya reseptor insulin yang terdapat pada membran sel yang responsir terhadap insulin.Etiologi lain : pankreatitis, tumor pankreas, obesitas, hipertiroid, akromegali, kehamilan, infeksi.

Sesuai dengan data pada atabel bahwa lansia rata-rata mengalami obesitas $>30$. Sebanyak 31 orang lansia dalam kondisi obesitas dimana didukung oleh aktifitas yang dilakukan lansia hanya 1-2 jam per harinya 
dan rata-rata tidak mengetahui riwayat Diabetes Mellitus. Kebiasaan makan banyak pada waktu muda menyebabkan berat badan berlebihan, apalagi pada lanjut usia penggunaan kalori berkurang karena berkurangnya aktivitas fisik. Kebiasaan makan tersebut sukar diubah walaupun disadari untuk mengurangi makan. Kegemukan merupakan salah satu pencetus berbagai penyakit, misalnya penyakit jantung, diabetes melitus, penyempitan pembuluh darah, dan tekanan darah tinggi.

Berkaitan dengan perubahan, kemudian Hurlock (1990) mengatakan bahwa perubahan yang dialami oleh setiap orang akan mempengaruhi minatnya terhadap perubahan tersebut dan akhirnya mempengaruhi pola hidupnya. Bagaimana sikap yang ditunjukan apakah memuaskan atau tidak memuaskan, hal ini tergantung dari pengaruh perubahan terhadap peran dan pengalaman pribadinya. Perubahan yang diminati oleh para lanjut usia adalah perubahan yang berkaitan dengan masalah peningkatan kesehatan, ekonmi atau pendapatan dan peran sosial (Goldstein, 1992).

Dalam menghadapi perubahan tersebut diperlukan penyesuaian. Ciri-ciri penyesuaian yang tidak baik dari lansia (Hurlock, 1979) di kutip oleh Munandar (1994) adalah :

1) Minat sempit terhadap kejadian di lingkungannya

2) penarikan diri ke dalam dunia fantasi

3) Selalu mengingat kembali masa lalu

4) Selalu kwuatir karena pengangguran

5) Kurang ada motivasi

6) Rasa kesendirian karena hubungan dengan keluarga kurang baik

7) Tempat tinggal yang tidak diinginkan

Ciri penyesuaian diri lanjut usia yang baik antara lain adalah : Minat yang kuat, ketidaktergantungan secara ekonomi, kontak sosial luas, menikmati kerja dan hasil kerja, menikmati kegiatan yang dilakukan saat ini dan memiliki kekuatiran minimal terhadap diri dan orang lain. 
Berbagai upaya dilakukan untuk mewujudkan lansia yang memeilki kualitas hidup yang optimal. Beberapa faktor yang berhubungan dengan kepuasan hidup orang lanjut usia, meliputi :

1) Kedekatan relasi personal.

Memiliki relasi yang dekat dengan orang lain adalah penting dalam kehidupan lanjut usia. Mereka yang memiliki sahabat karib merasakan kepuasan dengan hidup yang dijalaninya. Sejatinya bahwa semua orang memerlukan orang lain untuk berbagi perasaan, dipercayai dan mempercayai orang lain. Lanjut usia yang memiliki orang lain yang bisa dipercayai, menjadikan mereka mampu mengatasi berbagai cobaan yang muncul selama proses penuaan.

2) Pembiayaan.

Kesehatan dan pendapatan adalah dua faktor yang saling berhubungan erat dengan kepuasan hidup para lanjut usia. Ketika orang-orang berada dalam perasaan yang baik dan mempunyai uang, mereka dapat lebih aktif dalam kehidupannya, seperti pergi ke luar rumah untuk makan, mengunjungi tempat-tempat wisata, dan seterusnya, sehingga mereka memperoleh kebahagiaan dibanding mereka yang terus-terusan tinggal di rumah. Menabung sejumlah uang untuk cadangan pembiayaan dikehidupan mendatang menjadi penting, sekaligus sebagai pelajaran dalam mengatur anggaran dengan bijaksana.

3) Minat dan Hobi.

Secara psikologis orang-orang yang suka mengalami trauma karena memasuki pensiun (post power syndrome), mereka mengembangkan self-image dan minat dengan memusatkan pada pekerjaan. Orang yang mempunyai minat dan hobi yang bermakna dalam kehidupannya, setelah masa pensiun mencoba memanfaatkan waktu luangnya dengan melakukan aktivitas yang dapat menggantikan pekerjaan semula. 
4) Identitas Diri.

Orang yang merasa senang dan realistis terhadap kehidupannya sekarang dan apa yang mereka inginkan agar dapat hidup dengan lebih baik, merupakan kesiapan untuk mengatasi tekanan dan krisis yang mungkin terjadi.

5) Pandangan ke arah masa depan.

Orang yang selalu memikirkan masa lalunya atau pencapaian prestasi di masa lalu, cenderung mengalami depressi pada saat memasuki lanjut usia. Sementara orang yang memikirkan atau menantikan kehidupan di masa depan biasanya mempunyai minat yang tinggi untuk menemukan tantangan baru dan kepuasan baru dalam menjalani sisa waktu kehidupannya. Dengan berpandangan ke arah masa depan, seseorang dapat merencanakan ketika masa pensiun datang, seperti merencanakan dimana dan dengan siapa mereka akan tinggal, dengan masyarakat yang bagaimana mereka akan hidup bersama, dan merencanakan bagaimana memanfaatkan waktu yang tersedia dalam hidupnya.

6) Mengatasi Krisis.

Jika seseorang yang belum beranjak lanjut usia, sudah mulai belajar secara efektif bagaimana mengatasi krisis, hal ini merupakan keterampilan yang sangat bermanfaat ketika memasuki lanjut usia. Keefektifan cara mengatasi krisis tersebut merupakan pembelajaran untuk mengatasi permasalahan yang muncul secara realistis dan konstruktif.

Upaya penanganan pada pasien DM sekaligus juga pencegahan terjadinya komplikasi adalah teraturnya pasien DM melakukan aktifitas fisik (berolahraga). Dengan berolahraga diharapkan terjaganya kebugaran tubuh, menurunkan berat badan dan memperbaiki sensitivitas insulin, sehingga dapat memperbaiki kadar gula dalam darah. Pasien DM disarankan untuk berolahraga minimal 3 kali sepekan selama paling 
sedikit 30 menit $^{4}$. Olahraga yang disarankan adalah olahraga aerobik, seperti: jalan kaki, bersepeda, jogging, dan berenang. Olahraga disesuaikan dengan umur dan status kesegaran jasmani individu. Untuk pasien DM yang masih sehat, intensitas olahraga dapat ditingkatkan, namun untuk pasien yang telah mengalami komplikasi, olahraga dapat dikurangi.

Salah satu aktifitas fisik yang juga dianjurkan secara rutin adalah Gerakan Senam Kaki Diabetes / DM. Manfaat yang diharapkan dari gerakan kaki yang teratur dari senam kaki diabetes, adalah tidak terjadinya komplikasi yang sering terjadi pada kaki-kaki pasien DM seperti luka infeksi yang tidak sembuh dan menyebar. Senam kaki diabetes adalah suatu kegiatan atau latihan yang dilakukan oleh pasien diabetes mellitus untuk mencegah terjadinya luka dan membantu melancarkan peredaran darah bagian kaki.

Tujuan dan manfaat melakukan senam kaki antara lain memperbaiki sirkulasi darah, memperkuat otot-otot kecil, mencegah terjadinya kelainan bentuk kaki, meningkatkan kekuatan otot betis dan paha, mengatasi keterbatasan gerak. Cara melakukan gerakan senam kaki diabetes ini sangatlah mudah untuk dilakukan. Senam kaki diabetes bisa dilakukan di dalam maupun di luar ruangan. Tidak memerlukan waktu yang lama, karena hanya berlangsung sekitar 15-30 menit. Dan yang penting tidak memerlukan peralatan yang rumit, karena cukup dengan kursi dan sehelai koran bekas. Agar manfaat senam kaki diabetes lebih maksimal, penderita minimal melakukan gerakan senam kaki diabetes 3 kali sepekan, namun alangkah baiknya dapat dilakukan setiap hari. 


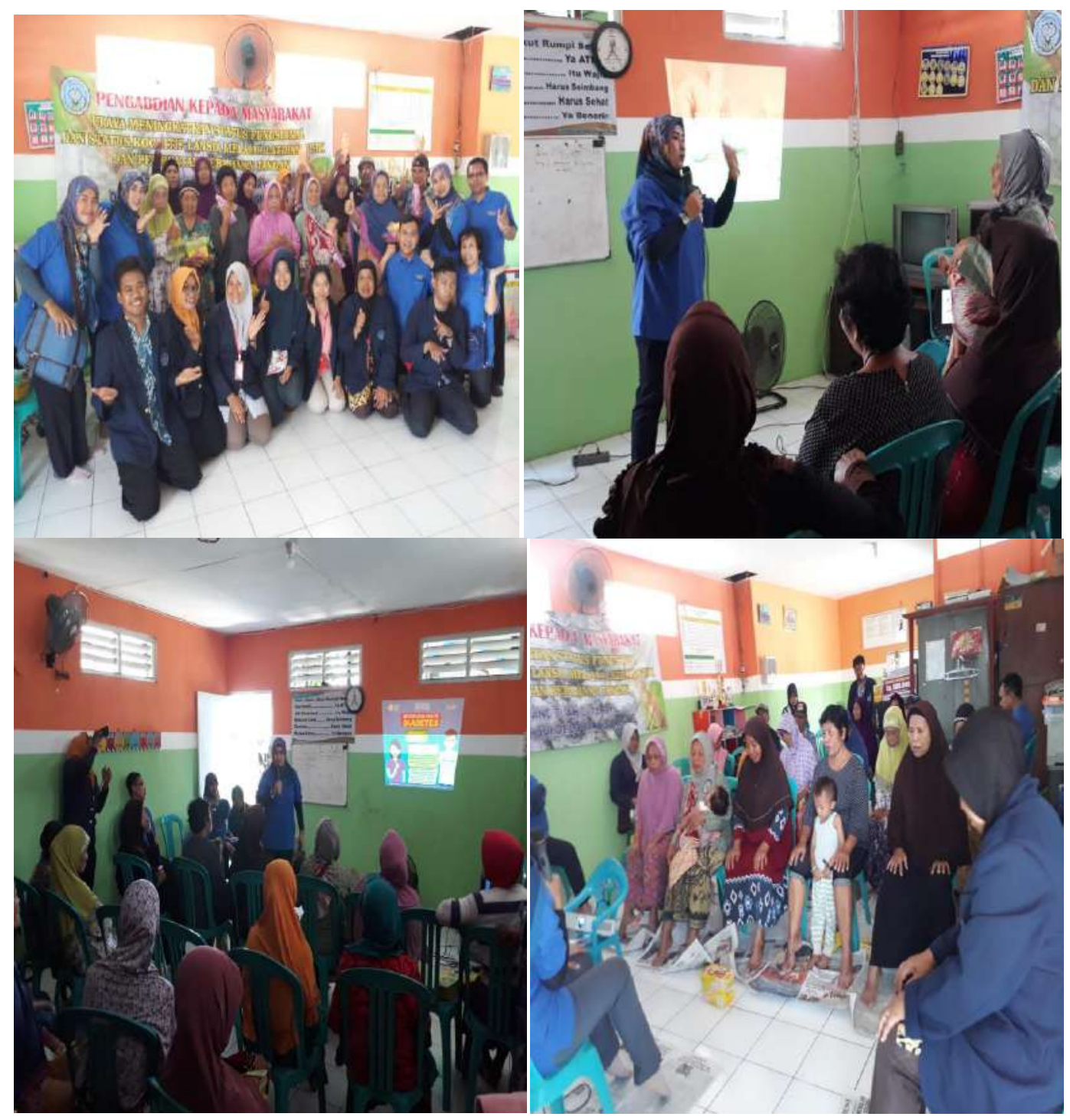

\section{SIMPULAN DAN SARAN}

\section{Simpulan}

Berdasarkan hasil dan luaran yang dicapai, maka dapat ditarik kesimpulan bahwa dengan adanya peningkatan pengetahuan tentang Diabetes Melitus yang merupakan penambahan informasi dan wawasan tentang kesehatan serta memeberikan gambaran yang jelas bagi lansia untuk pencegahan dan penatalaksanaannya. Begitu besar dampak dan komplikasi dari Diabetes Melitus seperti komplikasi akut (hipoglikemi) dan komplikasi kronis (gangren, retinopati, nefropati, neuropati, dll) sehingga perlu pencegahan dan penatalaksanaan lebih lanjut untuk tidak terjadi dampak yang lebih fatal 


\section{Saran}

Pengembangan program pengabdian masyarakat bidang peningkatan kualitas kesehatan lansia yang terintegrasi dengan program akademik, pemerintah dan stakeholder (mitra) perlu terus ditingkatkan. Serta perlunya kegiatan pengabdian masyarakat secara berkala dan berkelanjutan untuk lebih menggali lagi lebih dalam dalam masalahmasalah kesehatanyang dihadapi oleh para lansia

\section{UCAPAN TERIMAKASIH}

1. Ketua Stikes Hang Tuah Surabaya yang telah mendukung kegiatan pengabdian masyarakat ini baik dari segi moril maupun materiil dengan didukung oleh Surat Tugas Nomor :

2. Kepaga Kelurahan Sukolilo Kecamatan Bulak yang mendukung terselenggaranya kegiatan ini

3. Bapak lbu tenaga pendidik dan tenaga kependidikan, para mahasiswa STIKes Hang Tuah Surabaya serta Para Kader Kesehatan Posyandu Lansia RW.03 Kelurahan Sukolilo

\section{DAFTAR PUSTAKA}

1. Bastaki, Salim. 2005. Review Diabetes Mellitus and its Treatment. Department of Lawrence

2. Diabetes Mellitus. Http://wikipedia.org/diabetesmellitus/. Diakses tanggal 1 november 2010Skreela. 2010.

3. Diabetes Rehabilitation. www.commedtvm.org/phus/phu06_ session4.htm. Diakses tanggal 1 November 2010American Optometric Association. 2009.

4. Global Prevalence of Diabetes Estimates for the Year 2000 and Projections for 2030. Diabetes care 27:1047-1053, 2004 http://kesmas-unsoed.info/2010/12/makalah-diabetes-melitusepidemiologi-penyakit-tidak-menular.html 
5. M. Tierney, Jr. 2002. Current Medical Diagnosis \& Treatment, Adult Ambulatory \& Inpatient Management. McGraw-Hill Companier. New York, USA

6. Optometric Clinical Practice Guideline Care of the Patient with Diabetes Mellitus Reference Guide for Clinicians. Aoa Board of Trustees, USAWild, Sarah; Gojka Roglic, Anders Green; Richard Sicree, \& Hilary King. 2004.

7. Pharmacology, Faculty of Medicine \& Health Sciences, United Arab Emirates University, Al Ain United Arab Emirates. Int j Diabetes \& Metabolism (2005) 13:111-134 Anonim. 2010. 